\title{
Defining a Phenotypic Variability and Productivity in Wild Type Red Clover Germplasm
}

\author{
Giedrius Petrauskas ${ }^{1}$, Vaclovas Stukonis ${ }^{1} \&$ Egle Norkevičiené ${ }^{1}$ \\ ${ }^{1}$ Institute of Agriculture, Lithuanian Research Centre for Agriculture and Forestry, Akademija, Lithuania \\ Correspondence: Giedrius Petrauskas, Institute of Agriculture, Lithuanian Research Centre for Agriculture and \\ Forestry, LT-583-44 Akademija, Lithuania. E-mail: giedrius.petrauskas@lammc.lt
}

Received: June 29, 2020

Accepted: August 1, $2020 \quad$ Online Published: August 15, 2020

doi:10.5539/jas.v12n9p52

URL: https://doi.org/10.5539/jas.v12n9p52

\begin{abstract}
Abiotic and biotic factors can cause great damage to crops. So, a key approach is to investigate whether the crops' wild relatives are more flexible to withstand abiotic and biotic stress. As well as to evaluate their phenotypic variability and productivity in response to changing climatic conditions.

In this study, red clover germplasm was collected from natural red clover habitats and a field trial was arranged ex situ. Twelve phenotypic traits and their effects on final harvest were analysed in 2018-2019. Principal component analysis (PCA) demonstrated that the most important trait for biomass yield was the height of the plant during the first season of harvest (2018). Interestingly, that the most significant trait in the second year of harvest (2019) was growth habit. Meantime, two way-joining analysis was performed to extent of phenotypic variation within and among red clover accessions, based on the most important trait for biomass yield. We found three main groups based on variation in plant height: "cultivars", "wilds" and "mediators". This analysis leads to identify typical populations of wild type red clover, which has not been done yet. Finally, the feed value of each red clover accession was analysed. It was found that "cultivars" have a higher level of crude proteins, while "wilds" contains higher levels of crude fibre. This indicates that there is a relationship between plant structure elements and forage value which is particularly important to select a breeding material.
\end{abstract}

Keywords: autochthonous red clover, biodiversity, plant breeding, plant genetic resources

\section{Introduction}

Red clover (Trifolium pratense L.) is quite a common species, well-recognized by the public. Historically red clover is native to the Mediterranean basin. It spread around the world from the $16^{\text {th }}$ century as a consequence of expeditions of exploration and the settlement of new lands, projects which were at their most intense up to the $18^{\text {th }}$ century (Annicchiarico, Barrett, Brummer, Julier, \& Marshall, 2015; Taylor \& Quesenberry, 1996; Taylor, 2008).

Red clover became favoured due to its beneficial health properties. Its chemical composition was identified as equipment and laboratory methods improved at the turn of the $20^{\text {th }}$ century. It was found that red clover is rich in secondary metabolites: isoflavones, flavonoids, coumarin derivatives, cyanogenic glycosides, volatile oils, etc. (Vlaisavljević et al., 2017; Butkute et al., 2018). Even before this scientific validation, the value of red clover was recognized in organic farming, due to its ability convert and absorb atmospheric nitrogen in symbiosis with Rhizobium (Thilakarathna et al., 2016). Moreover, red clover is highly valued due to its high level of crude proteins and other feed qualities, therefore this species is widely used to implement greening programs and to feed cattle (Cassida et al., 2000). There are also beekeepers, who grown red clover for its high provision of nectar, although researchers report that red clover is a more suitable source of nectar for bumble bees than honey bees, who cannot reach the nectar from its long corolla tubes (Sands \& Rowntree, 2016; Vanommeslaeghe et al., 2018). While other studies have shown that bees pollinate red clover quite readily, especially the wild forms that have a shorter corolla tube than the cultivars (Rao \& Stephen, 2009; Vleugels et al., 2019).

Currently, there is a demand to breed new cultivars to meet the needs of consumers. It is desirable that new cultivar could be sustainable, functional, productive and flexible to address the challenges of global warming. Hopefully, the era of genomics can suggest different methods to improve and speed up the breeding process either within genome engineering using the CRISPR-Cas9 system or other genetic transformations (Beying, 
Schmidt, Pacher, Houben, \& Puchta, 2020). However, new and original genetic material is needed for breeding programmes. We are in agreement with researchers, that this need can be met by constant monitoring and by collecting germplasm from wild communities (Morris \& Greene, 2001; Solberg et al., 2017; Jones et al., 2020).

Unfortunately, information on the morphology of wild type red clover is not abundant and phenotyping of such crops wild relative is limited by lack of efficient techniques in situ (Moreira, Oliveira, Volenec, Rainey, \& Brito, 2020). Despite this challenge, it is important to assess and understand the potential of crops wild relative for adaptation to a changing climate and new habitats. Longitudinal monitoring is an effective method of assessing the most important traits and a basis on which to construct a model of future requirements under climate change (Moreira et al., 2020). The model would be useful if harvests were assessed and the most promising populations were chosen for breeding programs according to the selected traits. Inter alia, longitudinal monitoring can detect and demonstrate phenotypic variation within and between populations or cultivars. Moreover, a good model would promote reliable renewal of breeding material or complete elimination old cultivars from the market.

Statistically the model could be implemented, because expressed variation determines the power of variability which describes the potential for variation in population (Willmore et al., 2007). Solberg et al. (2017) have noted that variation in wild red clover may be a response to natural or artificial selection or even genetic drift, while the effects of climate change have forced the flora to adapt to abiotic and biotic factors (Gratani, 2014). Meantime, the most plastic individuals are adapted to survive, while these factors are acting in plant communities (Gratani, 2014; Pagnotta, Annicchiarico, Farina, \& Proietti, 2011). We believe this is strongly expressed in red clover populations because this species has different phenotypic types.

In this study, the phenotypic variability of wild red clover and its biological expression by integrating germplasm ex situ was analysed. In addition, the most important trait for biomass yield was distinguished and forage value was evaluated. Ultimately, a prototype for breeding was identified.

\section{Materials and Methods}

The research was carried out from 2016 to 2019. In the first year (2016) seeds were collected from wild populations inventoried as NATURA 2000 (codes 6510, 6530, 6270 and 6210) across Lithuania. Full ripened flower heads were threshed, and the seeds were sorted from admixture in each population. The seeds were dried for three months at $20{ }^{\circ} \mathrm{C}$ temperature during $15 \%$ relative humidity and then stored at $+4{ }^{\circ} \mathrm{C}$ until sowing began on 18 April 2017. Totally 49 accession of populations and cultivars were sown. Either, seeds of wild red clover which had been stored in the Lithuanian Plant Gene Bank (PGB) were used in this study. The seeds from PGB had been dried to $3-6 \%$ relative humidity and stored at $-18^{\circ} \mathrm{C}$ temperature for at least 10 years. Also, diploid cultivars of red clover bred in Lithuania ('Arimaičiai', 'Kamaniai' and 'Vytis') were used as accessions along with two diploid cultivars (2887 and 2889) that were received from other countries' PGBs. One tetraploid cultivar (2908) was used as control in relation to the diploid cultivars. Finally, cultivar 'Liepsna' was selected as a standard; this cultivar is one of the oldest and has been grown in Lithuania over long time period, therefore, it is likely that germplasm of 'Liepsna' have been spread to wild populations.

In the second year, on 18 April 2017 wild red clover seeds were sown in growing trays filled with a peat and soil mixture (30:70). While plants were transplanted ex situ on 10 July 2017. The field trial was arranged in a randomized complete block design with four replications, located at $55^{\circ} 23^{\prime} 35.0^{\prime \prime} \mathrm{N}, 23^{\circ} 52^{\prime} 38.6^{\prime \prime} \mathrm{E}$. Endocalcari-Epihypogleyic Cambisol soil with a moderately heavy loam texture predominates in the field. The soil $\mathrm{pH}_{\mathrm{KCl}} 7.5$, humus content $2.64 \%$, available $\mathrm{P}_{2} \mathrm{O}_{5} 220 \mathrm{mg} \mathrm{kg}^{-1}$ and $\mathrm{K}_{2} \mathrm{O} 156 \mathrm{mg} \mathrm{kg}^{-1}$. Fertilizers of $\mathrm{N}_{6} \mathrm{P}_{18} \mathrm{~K}_{34}$ $\left(24 \mathrm{~kg} \mathrm{~N}, 31 \mathrm{~kg} \mathrm{P}_{2} \mathrm{O}_{5}\right.$ and $113 \mathrm{~kg} \mathrm{~K}_{2} \mathrm{O}$ ) at a dose of $400 \mathrm{~kg} \mathrm{ha}^{-1}$ were spread before planting, while no fertilizer was used during the experiment. However, weeds were controlled mechanically and using active agent (a.i. bentazone $480 \mathrm{~g} \mathrm{l}^{-1}$ ) at dose of $960 \mathrm{~g} \mathrm{ha}^{-1}$ twice per season.

Twelve different agro-morphological parameters were evaluated during the first (2018) and second (2019) year of harvest. Abbreviations of measured and scored characteristics are shown in Table 1. Visual assessment of plant traits was performed based on the guidelines of the International Union for the Protection of New Varieties of Plants (2016). 
Table 1. Phenotypic and quality traits and their abbreviations

\begin{tabular}{lll}
\hline Abbreviation, units & Trait description & Determination method \\
\hline \#GRH, no & Growth habit & Score \\
\#NPH, cm & Natural plant height & Direct measurement \\
\#STL, cm & Stem length & Direct measurement \\
\#NOI, pcs & Number of internodes & Direct counting \\
\#MLL, cm & Length of central leaflet & Direct measurement \\
\#MLD, cm & Width of central leaflet & Direct measurement \\
\#ALM, no & Relative area of leaf markings & Score \\
\#ILM, no & Intensity of leaf markings & Score \\
\#LSH, no & Leaf shape & Score \\
\#FHN, pcs & Flower heads per plant & Direct counting \\
\#FHC, no & Intensity of flower head colour & Score \\
\#STC, no & Intensity of stem colour & Score \\
\#GMY, g & Green matter yield & Direct weighing \\
\#DMY, g & Dry matter yield & Direct weighing \\
\#CP, \% & Crude protein & IR spectrometry \\
\#CF, \% & Crude fibre & IR spectrometry \\
\#WSC, \% & Water-soluble carbohydrates & IR spectrometry \\
\hline
\end{tabular}

Green matter yield (GMY) and dry matter yield (DMY) were also measured during the second year of experiment (2018). Five plants per accession were cut manually. Each plant was put in a gauze bag and weighed separately with metrology calibration scales PNS-60 (Romasas, Lithuania). DMY was determined by drying the plants in a greenhouse and finishing them in an oven (at $105^{\circ} \mathrm{C}$ temperature) to fully dry.

The content of crude protein (CP), crude fibre (CF) and water-soluble carbohydrates (WSC) was determined by infrared spectrometer NIRS-6500 (Sensortech Systems Inc., USA) (Butkute et al., 2003). Five plants from each accession were taken and chopped into pieces of 3-5 cm length then dried at $105{ }^{\circ} \mathrm{C}$ for 15 min and finished at $65 \pm 5^{\circ} \mathrm{C}$ for $24 \mathrm{~h}$. Dry matter was ground in a cyclone mill and mixed well.

Meteorological conditions were observed during the evaluation and measurement of phenotypic traits in 20182019 (Figure 1). Climatic conditions were quite similar in 2018 and 2019 when there was severe drought, because of the low precipitation during the vegetation period plants were under stress.

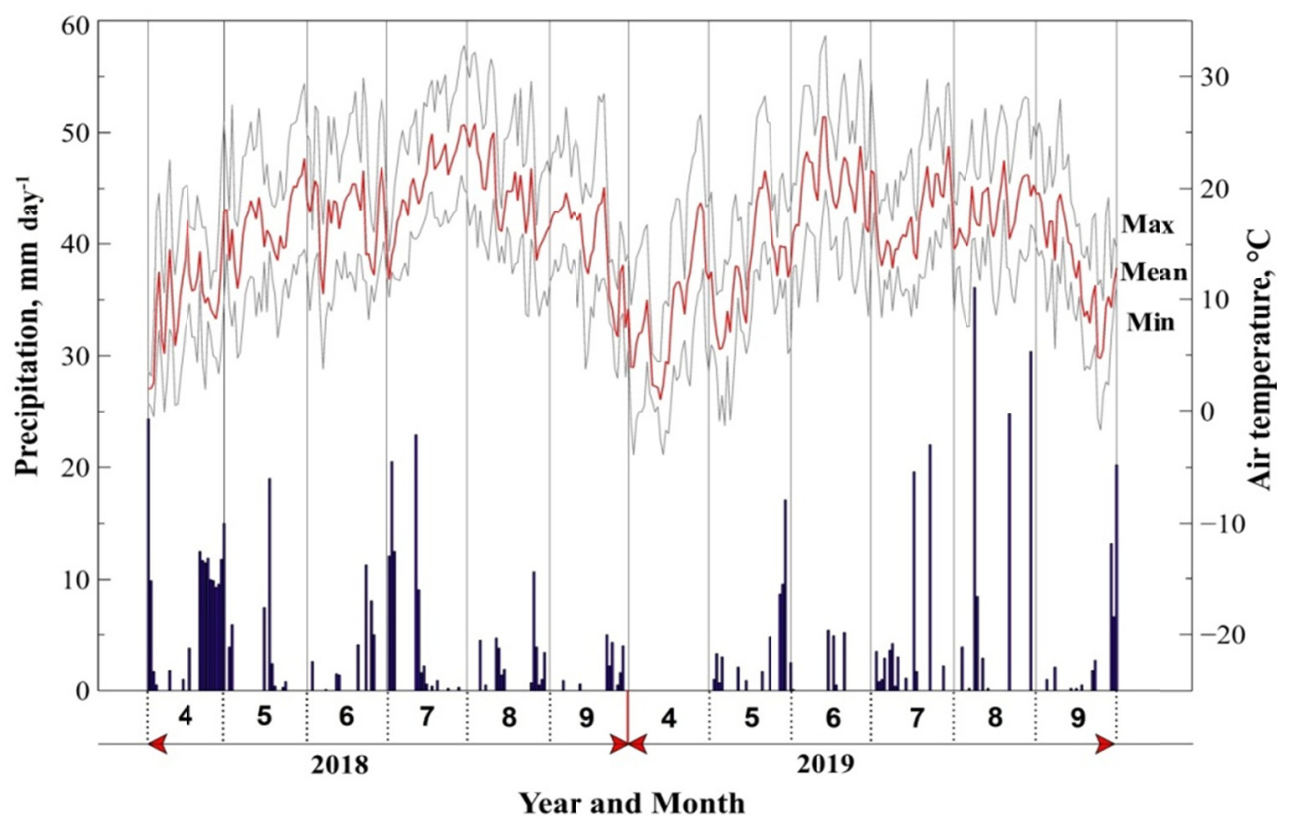

Figure 1. Meteorological conditions during 2018 and 2019 seasons at Dotnuva site $\left(55^{\circ} 23^{\prime} 35.0^{\prime \prime} \mathrm{N}, 23^{\circ} 52^{\prime} 38.6^{\prime \prime} \mathrm{E}\right)$, Lithuania 
Statistical analysis was performed using the softwares $S A S$, version 9.4 (SAS Institute Inc., USA) and $R$, version 4.0.0 (R Core Team). Principal component analysis (PCA) was used to determine the role of phenotypic traits in all data set during the first (2018) and second (2019) harvest year. Two-way joining cluster analysis was used to identify the variability of accessions and to group those accessions into clusters based on the factors that played the most important role in yield production. Each accession was compared to standard cultivar 'Liepsna', based on Dunnett's test, to identify significant differences $(P \leq 0.05)$.

\section{Results and Discussion}

PCA is a useful method to process a large number of traits; it creates independent variables called "principal components", that explains the variation in the whole dataset. Afterwards, the principal components become the new dependent variables in a multiple trait model (Mrode, 2014; Moreira et al., 2020), which is why PCAs are widely used to analyse multiple phenotyping traits.

\subsection{Importance of Phenotypic Traits for Yield}

The PCA results for phenotypic traits revealed that the first and second component explained less than $50 \%$ (only $47.86 \%$ ) of cases from whole dataset of red clover traits in 2018 (Figure 2), while $38.12 \%$ of cases was explained by the first and second component during 2019 season. The first principal component had the largest positive association with NPH, MLL, STL and MLD in 2018. So, this component primarily scored the most important traits for biomass yield. Thus, maximum weight of biomass is a complex of stems and leaves, which strongly correlate within NPH. Meantime, the second component has shown the highest negative association with FHN and NOI. As a result, this component primarily evaluated the traits that are not irrelevant for biomass yield, for instance as FHN. However, FHN is a priority indicator for seed yield, while the NOI is less important for biomass yield than NPH. Since biomass yield is more dependent on stem length, which consists of the sum of each individual internode length. Although, only $15.18 \%$ of cases in the total dataset during the harvest season of 2018 were explained by the second component, so it is less relevant to the final result then the first component.

First year of harvest (2018)

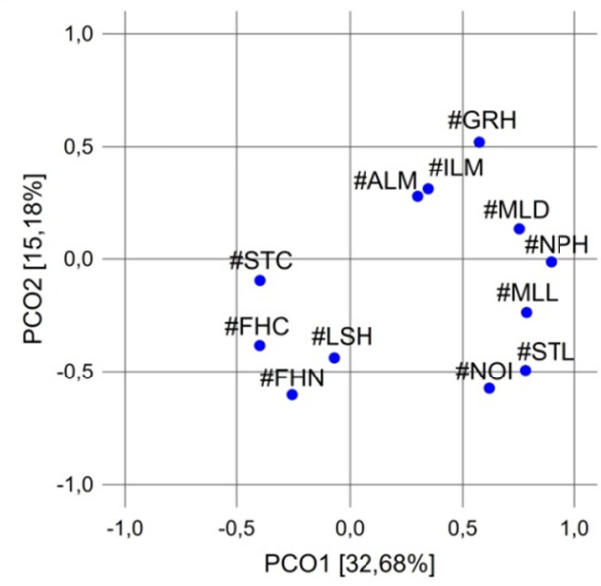

Second year of harvest (2019)

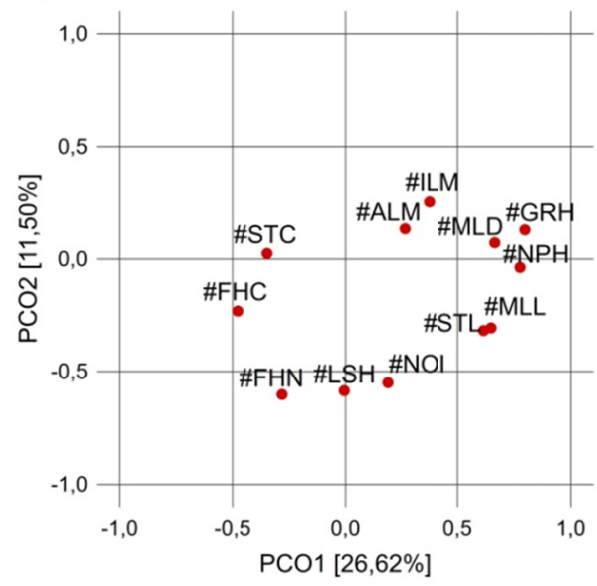

Figure 2. Principal component analysis (PCA) of phenotypic traits of red clover in 2018 and 2019

Note. Abbreviations of traits are explained in Table 1.

Current study revealed that GRH in the second year of harvest (2019) was the most important trait for biomass yield, NPH was the second most important trait, and STL was taken $5^{\text {th }}$ position of importance. Width and length of leaves were more influential than STL, which can be explained by the fact that NPH was lower and accessions had shorter STL during the second year of harvest. Meanwhile the effect of leaf size for the final biomass yield in the second year (2019) did not change significantly in compared to the first year of harvest (2018). Consequently, foliage and GRH played a more important role regarding final biomass yield during the 2019 season. As expected, the highest negative association was found in FHN and LSH in relation to the second component. Petrauskas et al. (2020) have reported that FHN is one of the major components for the hight seed yield production, while it is not so relevant for the biomass yield in this study. Finally, no significant role was found for LSH in relationship to foliage between harvest seasons. 
Summarizing, the PCA of the 12 phenotypic traits, demonstrates that NPH is the most important trait for biomass productivity in the first year of harvest (2018). While FHN is one of the least significant traits in regard to biomass, it is the most important trait for seed yield (Petrauskas et al., 2020). Although, the most important impact was made by GRH in the second year of harvest (2019).

\subsection{Phenotypic Variation Within and Among Populations}

Cluster analysis of two-way joining method was performed based on the most important trait of PCA for biomass yield. This two-way joining cluster is simultaneously based on both predictor and outcome variables. In population genetics this sort of application could be used to examine both phenotypic and genetic heterogeneity and homogeneity (Carja \& Plotkin, 2017). A major benefit of two-way joining method is that, it can be applied to create a model for variation in other phenotypic traits of this species and follow changes during years or generations.

In this study, 15 individual plants were assessed from each population. It was found that most majority of populations exhibited a higher variation than cultivars. Those populations and cultivars were grouped into three large groups (Figure 3). The first group, named "cultivars", consisted of cultivars and populations very closely related to them; it had low variation within accessions. The second group, named "wilds", consisted only of accessions referred to be as wild populations; the level of variation was quite similar to that of the group "cultivars", the only difference being that "wilds" are significantly different from "cultivars". Finally, the third group, the "mediators", consisted of accessions that were semi wild populations and had a high within group variation. Interestingly that, all the groups identified using two-way joining cluster analysis basically conformed to the statistical evaluation by Dunnett's test, so this model leads us to draw firm conclusions about the phenotypic hetero-homogeneity of the population according to the selected trait. In addition, this method enables outliers to be singled out that can be adopted for breeding programs or other research.

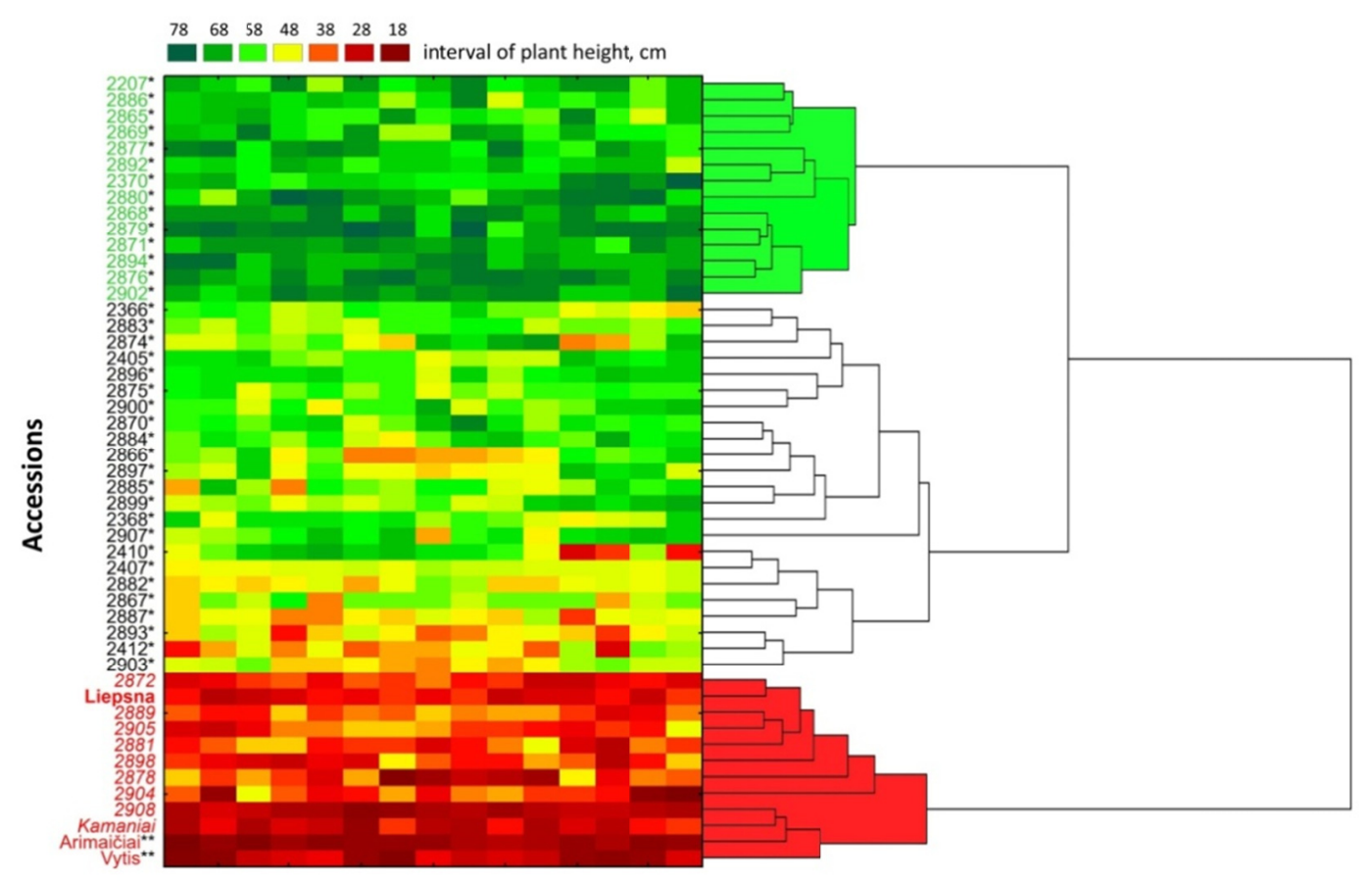

Figure 3. Two-way joining cluster analysis of natural plant height (NPH) variation within and among red clover accessions in 2018

Note. **: significantly higher, *: significantly lower than standard cultivar 'Liepsna', $P \leq 0.05$ (Dunnett's test).

The old Lithuanian cultivar 'Kamaniai' and two foreign cultivars 2908 and 2889 did not differ significantly in height compared to the standard cultivar 'Liepsna', whereas 'Arimaičiai' and 'Vytis' plants were significantly taller than 'Liepsna' in 2018. Moreover, no significant differences were found in NPH in relation to 'Liepsna' and populations $2904,2872,2905,2898,2881$ and 2878. Such morphological feature of NPH is not typical for 
wild type red clover. Most likely that these populations contain cultivars or they may be a consequence of gene flow from crossbreeding with cultivars (Taylor, Quesenberry, 1996; Van Minnebruggen et al., 2013). Meantime, no significant differences were found in the remaining 37 populations.

Further, the cultivars 'Kamaniai', 2887, 2908 and two populations 2872, 2883 did not differ significantly from the standard in height during the second year of harvest (2019) (Figure 4). However, 'Arimaičiai', 'Vytis', 2889 and all remaining 40 populations were significantly shorter than 'Liepsna'.

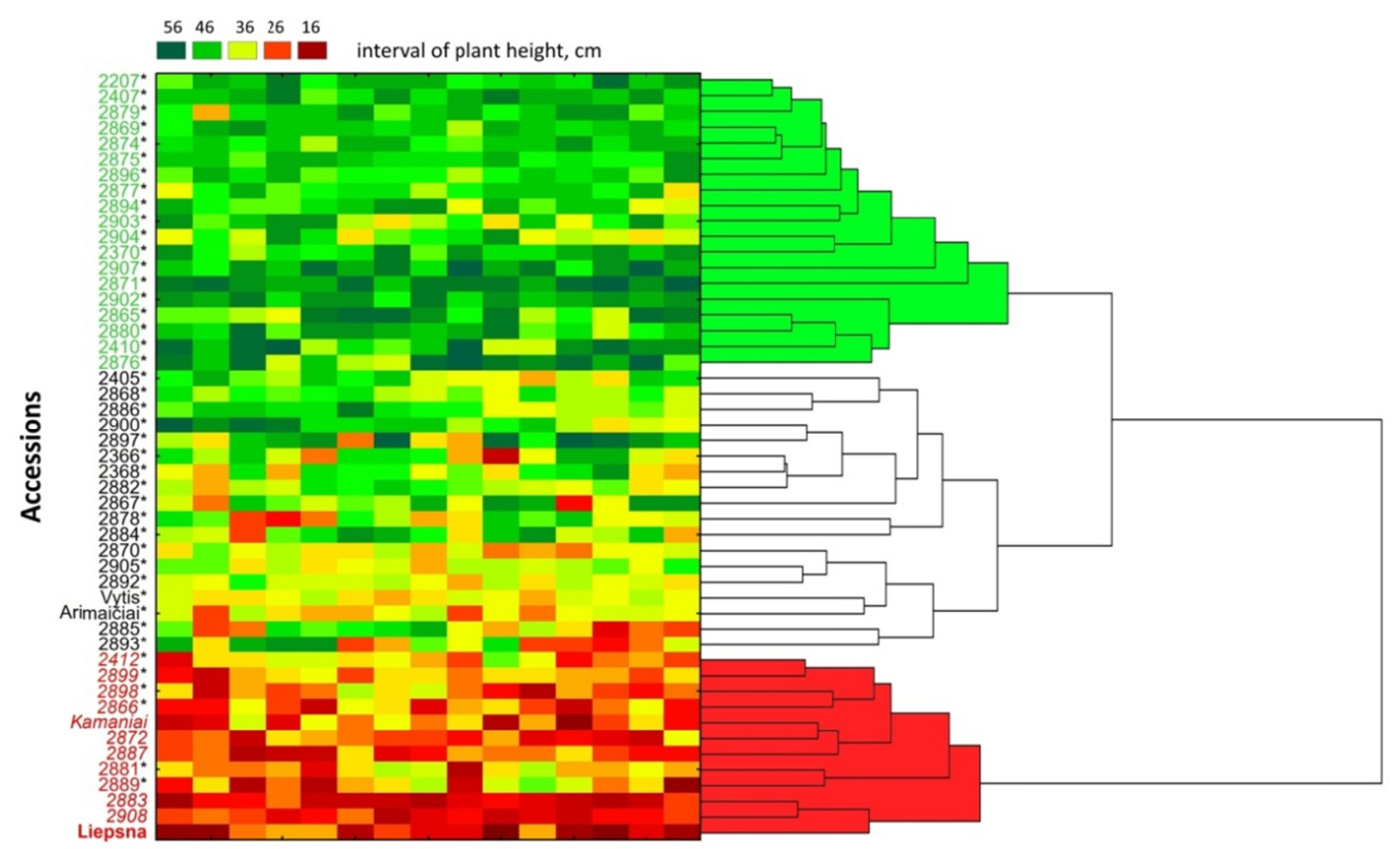

Figure 4. Two-way joining cluster analysis of natural plant height (NPH) variation within and among red clover accessions in 2019

Note. ${ }^{* *}$ : significantly higher, *: significantly lower than standard cultivar 'Liepsna', $P \leq 0.05$ (Dunnett's test).

Phenotypic variation in NPH within populations remained quite similar, while variation among populations decreased in the second year of harvest (2019). In other words, the plants got smaller in the second year (2019), and this way especially true of the cultivars. This outcome could be explained by plants plasticity in regard to regrowth after being cut (Herbert, Ekschmitt, Wissemann, \& Becker, 2018; Van Minnebruggen, Roldán-Ruiz, Van Bockstaele, Haesaert, \& Cnops, 2015). It is very likely that plants cannot regrow as tall as in the first year, and as a result, populations become more similar to the cultivars. Nonetheless, the cultivars were still taller than wild type red clover. The same result was noted by Jones et al. (2020), where wild populations failed to adapt to the cutting regime and regrowth was very poor.

Interestingly, that NPH of 'Arimaičiai' and 'Vytis' were significantly smaller in the second year (2019) although, these two cultivars were significantly taller than 'Liepsna' during the first harvesting season (2018). This suggests that 'Arimaičiai' and 'Vytis' are possibly less flexible in response to genotype and environment interaction $(G \times E)$ than 'Liepsna'. They may have been affected by abiotic factors such as overwintering conditions or drought stress. On the other hand, these two cultivars differ by genotypes, and as a result, they can have lower regrowth potential after being cut (Pagnotta et al., 2011; Jones et al., 2020). Another possible explanation for this outcome is that 'Arimaičiai' and 'Vytis' are newer breeds than 'Liepsna' and have lower capacity to cross-breed with other cultivars. In addition, 'Arimaičiai' and 'Vytis' have had less chance to pass on genetic changes to their progeny. (De Vega et al., 2015; Pagnotta et al., 2011).

\subsection{Biomass Yield and Feed Value}

Significantly higher green (GMY) and dry (DMY) matter yields per plant was found in three populations (2405, 2407 and 2899) and three cultivars ('Arimaičiai', 'Vytis' and 2889) than that which the standard cultivar 
'Liepsna' produced (Table 2). Meanwhile, four populations had a significantly higher DMY than 'Liepsna' but did not differ significantly in GMY. There was no significant different in GMY and DMY between all the remaining populations and the standard. The lowest GMY and DMY were found in population 2886 ( 0.334 and $0.094 \mathrm{~g}$, respectively), while the highest difference between GMY and DMY was found in the cultivar 'Kamaniai' $(0.996 \mathrm{~g})$. Thus, it can be stated that wild forms of red clover tend to produce a lower biomass yield; however, a significant difference depends on the relationship to that standard cultivar. Nevertheless, wild forms and landraces can be used to breed highly productive cultivars. Likewise, Hoekstra et al. (2018) reported that Switzerland locally adapted red clover landrace called "Mattenklees" produced a higher biomass yield than traditional cultivars of "Ackerklees" type.

Table 2. Values of biomass yield and forage quality in 2018

\begin{tabular}{|c|c|c|c|c|c|c|c|c|c|c|c|c|c|c|c|}
\hline Accession & $\begin{array}{l}\text { Mean of } \\
\text { GMY, kg }\end{array}$ & $\begin{array}{l}\text { Mean of } \\
\text { DMY, kg }\end{array}$ & $\begin{array}{l}\text { SE of } \\
\text { GMY }\end{array}$ & $\begin{array}{l}\text { SE of } \\
\text { DMY }\end{array}$ & $\begin{array}{l}\text { CP, } \\
\% \text { of } \\
\text { DMY }\end{array}$ & $\begin{array}{l}\text { CF, } \\
\% \text { of } \\
\text { DMY }\end{array}$ & $\begin{array}{l}\text { WSC, } \\
\% \text { of } \\
\text { DMY }\end{array}$ & Accession & $\begin{array}{l}\text { Mean of } \\
\text { GMY, kg }\end{array}$ & $\begin{array}{l}\text { Mean of } \\
\text { DMY, kg }\end{array}$ & $\begin{array}{l}\text { SE of } \\
\text { GMY }\end{array}$ & $\begin{array}{l}\text { SE of } \\
\text { DMY }\end{array}$ & $\begin{array}{l}\text { CP, } \\
\% \text { of } \\
\text { DMY }\end{array}$ & $\begin{array}{l}\text { CF, } \\
\% \text { of } \\
\text { DMY }\end{array}$ & $\begin{array}{l}\text { WSC, } \\
\% \text { of } \\
\text { DMY }\end{array}$ \\
\hline Liepsna & 0.656 & 0.154 & 0.098 & 0.021 & 17.6 & 28.6 & 9.06 & 2882 & 0.56 & 0.154 & 0.079 & 0.015 & 15.6 & 31.8 & 7.43 \\
\hline 2207 & 0.464 & 0.128 & 0.035 & 0.008 & 14.8 & 27.2 & 6.67 & 2883 & 0.596 & 0.148 & 0.088 & 0.020 & 15.0 & 28.9 & 6.72 \\
\hline 2366 & 0.778 & 0.188 & 0.032 & 0.011 & 16.8 & 28.3 & 8.53 & 2884 & 0.53 & 0.132 & 0.086 & 0.016 & 16.3 & 26.0 & 7.69 \\
\hline 2368 & 0.844 & 0.168 & 0.081 & 0.019 & 15.4 & 30.3 & 6.76 & 2885 & 0.49 & 0.148 & 0.081 & 0.017 & 15.8 & 33.0 & 5.99 \\
\hline 2370 & 0.836 & 0.234 & 0.102 & 0.037 & 14.0 & 29.3 & 6.90 & 2886 & 0.334 & 0.094 & 0.024 & 0.009 & 16.3 & 30.8 & 6.51 \\
\hline 2405 & $1.208^{*}$ & $0.306^{*}$ & 0.088 & 0.028 & 14.0 & 32.9 & 6.43 & 2887 & 0.466 & 0.128 & 0.064 & 0.015 & 19.7 & 24.3 & 8.67 \\
\hline 2407 & $1.19 *$ & $0.322 *$ & 0.154 & 0.013 & 14.1 & 31.4 & 7.20 & 2889 & $1.024^{*}$ & $0.306^{*}$ & 0.156 & 0.040 & 13.9 & 30.6 & 9.84 \\
\hline 2410 & 0.794 & 0.256 & 0.104 & 0.036 & 14.2 & 29.6 & 8.37 & 2892 & 0.384 & 0.12 & 0.099 & 0.021 & 17.8 & 29.5 & 6.75 \\
\hline 2412 & 0.696 & 0.182 & 0.095 & 0.020 & 18.3 & 27.5 & 7.81 & 2893 & 0.57 & $0.322^{*}$ & 0.075 & 0.046 & 17.3 & 25.9 & 9.26 \\
\hline 2865 & 0.74 & 0.194 & 0.089 & 0.017 & 18.3 & 28.5 & 7.51 & 2894 & 0.392 & 0.114 & 0.048 & 0.011 & 16.9 & 30.2 & 6.21 \\
\hline 2866 & 0.64 & 0.168 & 0.055 & 0.015 & 16.6 & 28.5 & 7.26 & 2896 & 1.13 & $0.346^{*}$ & 0.119 & 0.047 & 12.7 & 29.3 & 7.48 \\
\hline 2867 & 0.598 & 0.170 & 0.125 & 0.033 & 16.0 & 30.3 & 7.37 & 2897 & 0.814 & 0.226 & 0.114 & 0.048 & 12.3 & 27.6 & 6.88 \\
\hline 2868 & 0.516 & 0.136 & 0.057 & 0.012 & 13.8 & 32.3 & 7.40 & 2898 & 0.864 & 0.172 & 0.132 & 0.031 & 16.7 & 28.7 & 9.24 \\
\hline 2869 & 0.882 & 0.234 & 0.087 & 0.025 & 14.8 & 30.9 & 6.42 & 2899 & $1.146^{*}$ & $0.356^{*}$ & 0.128 & 0.048 & 13.8 & 32.1 & 6.36 \\
\hline 2870 & 0.59 & 0.152 & 0.068 & 0.019 & 15.4 & 31.1 & 7.70 & 2900 & 0.556 & 0.232 & 0.080 & 0.029 & 15.2 & 28.3 & 5.90 \\
\hline 2871 & 0.384 & 0.112 & 0.060 & 0.014 & 15.2 & 32.3 & 7.68 & 2902 & 0.646 & 0.244 & 0.061 & 0.013 & 10.6 & 27.8 & 7.76 \\
\hline 2872 & 0.594 & 0.172 & 0.090 & 0.021 & 18.4 & 27.1 & 8.17 & 2903 & 0.654 & 0.148 & 0.050 & 0.010 & 15.4 & 28.5 & 7.85 \\
\hline 2874 & 0.698 & 0.258 & 0.079 & 0.029 & 14.8 & 28.9 & 8.98 & 2904 & 0.91 & 0.204 & 0.184 & 0.037 & 13.1 & 30.6 & 6.59 \\
\hline 2875 & 0.898 & $0.322^{*}$ & 0.153 & 0.046 & 14.9 & 29.9 & 6.36 & 2905 & 0.82 & 0.164 & 0.098 & 0.025 & 17.9 & 28.5 & 7.78 \\
\hline 2876 & 0.554 & 0.140 & 0.085 & 0.021 & 17.7 & 28.5 & 5.71 & 2907 & 0.86 & $0.278^{*}$ & 0.106 & 0.024 & 13.6 & 31.1 & 6.93 \\
\hline 2877 & 0.444 & 0.138 & 0.083 & 0.022 & 16.0 & 29.8 & 6.81 & 2908 & 0.812 & 0.164 & 0.130 & 0.020 & 18.5 & 26.2 & 9.02 \\
\hline 2878 & 0.666 & 0.172 & 0.082 & 0.018 & 15.4 & 30.7 & 8.36 & Arimaičiai & $1.142 *$ & $0.336^{*}$ & 0.106 & 0.016 & 14.0 & 29.7 & 8.87 \\
\hline 2879 & 0.578 & 0.138 & 0.118 & 0.019 & 17.3 & 27.2 & 7.57 & Kamaniai & $1.226^{*}$ & 0.230 & 0.114 & 0.031 & 14.5 & 29.6 & 8.76 \\
\hline 2880 & 0.514 & 0.132 & 0.150 & 0.031 & 16.8 & 29.0 & 6.90 & Vytis & $1.318^{*}$ & 0.382 * & 0.047 & 0.028 & 16.7 & 28.2 & 10.2 \\
\hline 2881 & 0.676 & 0.198 & 0.036 & 0.017 & 17.2 & 29.0 & 8.12 & & & & & & & & \\
\hline
\end{tabular}

Note. *: significantly higher than standard cultivar 'Liepsna' $P \leq 0.05$ (Dunnett's test).

In terms of feed quality indicators, the lowest amount of CP was found in the population $2902(10.6 \%)$, and the highest in cultivar 2887 (19.7\%), while 'Liepsna' tended to produce 17.6\% CP which is higher than that found in other Lithuanian bred cultivars. The lowest content of CF was found in cultivar 2887, while the highest quantity was produced by population 2885. Meantime 'Liepsna' had $28.6 \% \mathrm{CF}$, which was a lower amount than 'Kamaniai', 'Arimaičiai' and the remaining 27 populations produced.

It was found that population 2876 had the lowest water-soluble carbohydrates (WSC) content (5.71\%), while 'Vytis' tended to produce $10.2 \%$, which was the highest amount of WSC among all accessions, including the standard cultivar 'Liepsna' (9.06\%). Meanwhile, two populations (2893 and 2898) were characterized by higher WSC content than the standard. Thus, we may conclude that red clover tends to produce higher levels of WSC in response to $\mathrm{G} \times \mathrm{E}$ interaction.

Results of our experiment showed that those populations tend to form more stems with smaller leaves than cultivars, and those stems contain a higher percentage of CF than leaves, whereas cultivars have a higher percent of CP due to their higher leaf to stem ratio (Hoekstra et al., 2018; Tucak, Popović, Čupić, Španić, \& Meglič, 2013). Meantime, WSC content is more dependent on the environmental factors such as drought and even depends on the time of day (Kagan et al., 2020; Ruckle et al., 2017). Thus, the highest amounts of CP are 
accumulated in the leaves (Taylor, Quesenberry, 1996). CF strongly negatively correlates with CP, so populations with higher CP level tend to have lower CF levels and vice versa (Hai-xia et al., 2013). Similar trends of CP were noted by Hoekstra et al. (2018), who reported that CP concentration differed slightly between cultivars, while there was a significant difference between cultivars and landrace type.

However, there is a lack of information about the feed quality of wild type red clover, while there is more data about breeding lines which are bred for several generations ex situ and seemed to differ from their ancestors.

\section{Conclusions}

Natural plant height (NPH) in the first year of harvest (2018) was the most important trait for biomass yield. Whereas grow habit (GRH) became the most important indicator in the second year of harvest (2019), with NPH and all other traits becoming less influential.

High variation of NPH was found within populations, while the low variation was identified among those populations in terms of NPH. This shows that NPH lost relevance in the second year of harvest (2019) and all accessions became more resemble.

GRH was constrained by the biological potential of plants to regrow after being cut. Results of our experiment confirms the claim that cultivars' regrowth ratio is higher than that of wild populations.

Two way joining analysis based on the most important traits for biomass yield have clustered red clover accessions in three groups "cultivars", "wilds" and "mediators". The largest group between them all was "mediators", who stood out with a high phenotypic variability within each population.

The vast majority of the populations in the field trial produced a lower green (GMY) and dry (DMY) matter yields than the standard cultivar 'Liepsna' but did not differ significantly.

The cultivars attended to produce higher rate of foliage; as a result, plants had higher crude protein (CP) content. Meantime, wild red clover populations were found to have a high stem-leaf ratio, thus producing a higher proportion of crude fibre (CF) than that of cultivars.

\section{Acknowledgements}

This study is being funded through the long-term research program "Genetics and purposeful change of genotypes of agricultural and forest plants" implemented by the Lithuanian Research Centre for Agriculture and Forestry. Also, we would like to thank senior researchers Dr. Kristina Jaškūnė and Dr. Vilma Kemešytė for proofreading the first version of manuscript.

\section{References}

Annicchiarico, P., Barrett, B., Brummer, E. C., Julier, B., \& Marshall, A. H. (2015). Achievements and Challenges in Improving Temperate Perennial Forage Legumes. Critical Reviews in Plant Sciences, 34(1-3), 327-380. https://doi.org/10.1080/07352689.2014.898462

Beying, N., Schmidt, C., Pacher, M., Houben, A., \& Puchta, H. (2020). CRISPR-Cas9-mediated induction of heritable chromosomal translocations in Arabidopsis. Nature Plants, 6, 638-645. https://doi.org/10.1038/ s41477-020-0663-x

Butkute, B., Mašauskienè, A., \& Paplauskienè, V. (2003). Database collecting and development of calibration equations for the evaluation of chemical composition of grasses by a NIR spectrophotometer. Zemdirbyste-Agriculture, 82(2), 157-158.

Butkutè, B., Taujenis, L., \& Norkevičienè, E. (2018). Small-Seeded Legumes as a Novel Food Source. Variation of Nutritional, Mineral and Phytochemical Profiles in the Chain: Raw Seeds-Sprouted Seeds-Microgreens. Molecules, 24(1), 133. https://doi.org/10.3390/molecules24010133

Carja, O., \& Plotkin, J. B. (2017). The evolutionary advantage of heritable phenotypic heterogeneity. Scientific Reports, 7(1), 5090. https://doi.org/10.1038/s41598-017-05214-2

Cassida, K. A., Griffin, T. S., Rodriguez, J., Patching, S. C., Hesterman, O. B., \& Rust, S. R. (2000). Protein Degradability and Forage Quality in Maturing Alfalfa, Red Clover, and Birdsfoot Trefoil. Crop Science, 40(1), 209-215. https://doi.org/10.2135/cropsci2000.401209x

De Vega, J. J., Ayling, S., Hegarty, M., Kudrna, D., Goicoechea, J. L., Ergon, Å., ... Skøt, L. (2015). Red clover (Trifolium pratense L.) draft genome provides a platform for trait improvement. Scientific Reports, 5(1), 17394. https://doi.org/10.1038/srep17394 
Gratani, L. (2014). Plant Phenotypic Plasticity in Response to Environmental Factors. Advances in Botany, 2014, 1-17. https://doi.org/10.1155/2014/208747

Hai-xia, Z., Xue, L., Yan-bin, W., Xiu-jie, Y., Qin-wei, Y., \& Ya-jun, C. (2013). Nutrient Status and Dynamics of Trifolium spp. at Different Growing Stages. Journal of Northeast Agricultural University (English Edition), 20(3), 6-11. https://doi.org/10.1016/S1006-8104(14)60002-7

Herbert, D. B., Ekschmitt, K., Wissemann, V., \& Becker, A. (2018). Cutting reduces variation in biomass production of forage crops and allows low-performers to catch up: A case study of Trifolium pratense L. (red clover). Plant Biology, 20(3), 465-473. https://doi.org/10.1111/plb.12695

Hoekstra, N. J., De Deyn, G. B., Xu, Y., Prinsen, R., \& Van Eekeren, N. (2018). Red clover varieties of Mattenklee type have higher production, protein yield and persistence than Ackerklee types in grass-clover mixtures. Grass and Forage Science, 73(2), 297-308. https://doi.org/10.1111/gfs.12307

UPOV (International Convention for the Protection of New Varieties of Plants). (2016). Red clover. Retrieved from https://www.upov.int/meetings/en/doc_details.jsp?meeting_id=42986\&doc_id=372952v

Jones, C., De Vega, J., Lloyd, D., Hegarty, M., Ayling, S., Powell, W., \& Skøt, L. (2020). Population structure and genetic diversity in red clover (Trifolium pratense L.) germplasm. Scientific Reports, 10(1), 8364. https://doi.org/10.1038/s41598-020-64989-z

Kagan, I. A., Anderson, M. L., Kramer, K. J., Seman, D. H., Lawrence, L. M., \& Smith, S. R. (2020). Seasonal and Diurnal Variation in Water-Soluble Carbohydrate Concentrations of Repeatedly Defoliated Red and White Clovers in Central Kentucky. Journal of Equine Veterinary Science, 84, 102858. https://doi.org/ 10.1016/j.jevs.2019.102858

Moreira, F. F., Oliveira, H. R., Volenec, J. J., Rainey, K. M., \& Brito, L. F. (2020). Integrating High-Throughput Phenotyping and Statistical Genomic Methods to Genetically Improve Longitudinal Traits in Crops. Frontiers in Plant Science, 11. https://doi.org/10.3389/fpls.2020.00681

Morris, J. B., \& Greene, S. L. (2001). Defining a Multiple-Use Germplasm Collection for the Genus Trifolium. Crop Science, 41(3), 893-901. https://doi.org/10.2135/cropsci2001.413893x

Pagnotta, M. A., Annicchiarico, P., Farina, A., \& Proietti, S. (2011). Characterizing the molecular and morphophysiological diversity of Italian red clover. Euphytica, 179(3), 393-404. https://doi.org/10.1007/ s10681-010-0333-6

Petrauskas, G., Norkevičienė, E., Stukonis, V., \& Kemešytė, V. (2020). Phenotypic traits for wild red clover seed yield under drought conditions. Czech Journal of Genetics and Plant Breeding. https://doi.org/10.17221/ 111/2019-CJGPB

Rao, S., \& Stephen, W. P. (2009). Bumble Bee Pollinators in Red Clover Seed Production. Crop Science, 49(6), 2207-2214. https://doi.org/10.2135/cropsci2009.01.0003

Ruckle, M., Meier, M., Frey, L., Eicke, S., Kölliker, R., Zeeman, S., \& Studer, B. (2017). Diurnal Leaf Starch Content: An Orphan Trait in Forage Legumes. Agronomy, 7(1), 16. https://doi.org/10.3390/agronomy 7010016

Sands, R. J., \& Rowntree, J. K. (2016). Interactions between the Bumblebee Bombus pascuorum and Red Clover (Trifolium pratense) Are Mediated by Plant Genetic Background. PLOS ONE, 11(8), e0161327. https://doi.org/10.1371/journal.pone.0161327

Solberg, S. O., Yndgaard, F., \& Palmè, A. (2017). Morphological and phenological consequences of ex situ conservation of natural populations of red clover (Trifolium pratense L.). Plant Genetic Resources, 15(2), 97-108. https://doi.org/10.1017/S1479262115000416

Taylor, N. L., \& Quesenberry, K. H. (1996). Red Clover Science. https://doi.org/10.1007/978-94-015-8692-4

Taylor, N. L. (2008). A Century of Clover Breeding Developments in the United States. Crop Science, 48(1), 1-13. https://doi.org/10.2135/cropsci2007.08.0446

Thilakarathna, M. S., Papadopoulos, Y. A., Rodd, A. V., Grimmett, M., Fillmore, S. A. E., Crouse, M., \& Prithiviraj, B. (2016). Nitrogen fixation and transfer of red clover genotypes under legume-grass forage based production systems. Nutrient Cycling in Agroecosystems, 106(2), 233-247. https://doi.org/10.1007/ s10705-016-9802-1 
Tucak, M., Popović, S., Čupić, T., Španić, V., \& Meglič, V. (2013). Variation in yield, forage quality and morphological traits of red clover (Trifolium pratense L.) breeding populations and cultivars. Zemdirbyste-Agriculture, 100(1), 63-70. https://doi.org/10.13080/z-a.2013.100.009

Van Minnebruggen, A., Roldán-Ruiz, I., Van Bockstaele, E., Haesaert, G., \& Cnops, G. (2015). The relationship between architectural characteristics and regrowth in Trifolium pratense (red clover). Grass and Forage Science, 70(3), 507-518. https://doi.org/10.1111/gfs.12138

Van Minnebruggen, A., Roldan-Ruiz, I., Van Dingenen, J., Van Bockstaele, E., Rohde, A., \& Cnops, G. (2013). Morphological and Molecular Characterization of Branching in Red Clover (Trifolium pratense). Breeding strategies for sustainable forage and turf grass improvement (pp. 161-167). https://doi.org/10.1007/ 978-94-007-4555-1_20

Vanommeslaeghe, A., Meeus, I., Cnops, G., Vleugels, T., Merchiers, M., Duquenne, B., ... Smagghe, G. (2018). Influence of pollinator abundance and flower visitation on seed yield in red clover. Arthropod-Plant Interactions, 12(3), 339-349. https://doi.org/10.1007/s11829-017-9593-6

Vlaisavljević, S., Kaurinović, B., Popović, M., \& Vasiljević, S. (2017). Profile of phenolic compounds in Trifolium pratense L. extracts at different growth stages and their biological activities. International Journal of Food Properties, 20(12), 3090-3101. https://doi.org/10.1080/10942912.2016.1273235

Vleugels, T., Amdahl, H., Roldán-Ruiz, I., \& Cnops, G. (2019). Factors Underlying Seed Yield in Red Clover: Review of Current Knowledge and Perspectives. Agronomy, 9(12), 829. https://doi.org/10.3390/agronomy 9120829

Willmore, K. E., Young, N. M., \& Richtsmeier, J. T. (2007). Phenotypic Variability: Its Components, Measurement and Underlying Developmental Processes. Evolutionary Biology, 34(3-4), 99-120. https://doi.org/10.1007/s11692-007-9008-1

\section{Copyrights}

Copyright for this article is retained by the author(s), with first publication rights granted to the journal.

This is an open-access article distributed under the terms and conditions of the Creative Commons Attribution license (http://creativecommons.org/licenses/by/4.0/). 